\title{
Kemampuan Pemecahan Masalah dan Keyakinan Calon Guru dalam Menyelesaikan Soal Pemecahan Masalah
}

\author{
Nasrullah $^{1}$, Rahmah Johar ${ }^{1}$, Said Munzir ${ }^{1}$ \\ ${ }^{1}$ Pendidikan Matematika-FKIP Universitas Syiah Kuala
}

\begin{tabular}{l}
\hline \hline INFO ARTIKEL \\
\hline Riwayat Artikel: \\
Diterima: 06-01-2019 \\
Disetujui: 16-03-2019 \\
\hline
\end{tabular}

\section{Kata kunci:}

solution to problem; prospective teacher; mathematics; pemecahan masalah; calon guru; matematika

\begin{abstract}
ABSTRAK
Abstract: This study aims to analyze the problem solving abilities and beliefs of prospective teachers in solving problem solving problems. The type of research used in this study is descriptive research with a qualitative approach. Based on this research, it is known that students with different abilities can do problem solving procedures, ranging from understanding problems, planning, carrying out problem solving and checking again but the results are different in each ability. Students' confidence in solving problem solving problems is relatively the same for all levels of ability, namely they believe that solving problems solving problems takes a long time, except that the length of time required for each level of the subject is different. The three subjects also believe that problem solving is useful in learning mathematics and in everyday life. They also believe that problem-solving abilities can be improved by the learning process
\end{abstract}

\begin{abstract}
Abstrak: Penelitian ini bertujuan untuk analisis kemampuan pemecahan masalah dan keyakinan calon guru dalam menyelesaikan soal pemecahan masalah. Jenis penelitian yang digunakan dalam penelitian ini adalah penelitian deskriptif dengan pendekatan kualitatif. Berdasarkan penelitian ini diketahui mahasiswa dengan kemampuan berbeda dapat melakukan prosedur pemecahan masalah, mulai dari memahami masalah, merencanakan, melaksanakan pemecahan masalah dan memeriksa kembali, tetapi hasilnya berbeda pada setiap kemampuan. Keyakinan mahasiswa dalam menyelesaikan soal pemecahan masalah relatif sama untuk semua tingkat kemampuan, yaitu mereka yakin menyelesaikan soal pemecahan masalah membutuhkan waktu yang lama, hanya saja lama waktu yang dibutuhkan untuk masing-masing tingkatan subjek berbeda. Ketiga subjek juga yakin bahwa pemecahan masalah berguna dalam pembelajaran matematika dan dalam kehidupan sehari-hari. Mereka juga yakin bahwa kemampuan pemecahan masalah dapat ditingkatkan dengan proses belajar.
\end{abstract}

\section{Alamat Korespondensi:}

\section{Nasrullah}

Pendidikan Matematika

Universitas Syiah Kuala-Banda Aceh

Jalan Tgk. Hasan Krueng Kalee, Kopelma Darussalam, Syiah Kuala, Kota Banda Aceh, Aceh 23111

E-mail: nasrullaharul25@gmail.com

Kemampuan pemecahan masalah merupakan salah satu kemampuan yang harus dimiliki oleh guru matematika. Bagi seorang guru pemecahan masalah berarti tidak hanya menemukan solusi dari masalah matematika, tetapi juga menghadapi situasi baru dan menemukan solusi yang fleksibel, berguna dan elegan terhadap situasi ini. Olving mengatakan masalah untuk seorang guru matematika berarti sebuah pertanyaan yang luar biasa dimana siswa memiliki informasi awal yang diperlukan, namun mereka tidak mengetahui cara dan langkah yang akan mengarahkan mereka pada solusi sebelumnya, sehingga dibutuhkan kemampuan seoarang guru yang bisa mengambil keputusan yang tepat dan cepat terhadap masalah tersebut (Olving, Etacognition, \& Schoenfeld, 1992). Jonassen mengatakan pemecahan masalah umumnya dianggap sebagai aktivitas kognitif paling penting dalam proses pembelajaran sehari-hari (Jonassen, 2000).

Hasil penelitian terhadap 20 orang mahasiswa calon guru matematika yang dilakukan oleh Nissa dan Lestari menunjukkan bahwa calon guru matematika tidak memahami dengan baik mengenai teori problem solving dan belum kaya dengan teknik memecahkan masalah maupun membuat problem matematika (Nissa, \& Lestari, 2015). Selain kemampuan pemecahan masalah, keyakinan merupakan sesuatuyang penting dalam pembelajaran matematika. Hal ini sesuai dengan pendapat Pajares yang mengungkapkan Keyakinan ini memiliki tempat penting dalam proses belajar mengajar karena memengaruhi persepsi individu (Pajares, 2007). Llinares juga mengatakan keyakinan calon guru menjadi perhatian penting dalam program pendidikan guru (Llinares, 2002). Mereka belajar mengajar dari apa yang mereka ketahui dan percaya tentang mengajarkan materi pelajaran dari tahun ke tahun. 
Selain itu, keyakinan calon guru juga dapat memengaruhi cara mereka melakukan proses pembelajaran dalam beberapa tahun pertama mereka memasuki dunia guru yang sebenarnya. Keyakinan guru merupakan faktor penting yang memengaruhi baik lingkungan kelas yang mereka ciptakan dan keyakinan siswa tentang matematika (Ball, 1990). Penelitian tentang pemecahan masalah dan keyakinan telah dilakukan oleh beberapa peneliti, Yavuz dan Erbay menganalisis keyakinan calon tentang pemecahan masalah matematika dalam hal berbagai variabel dengan membandingkan mahasiswa dari dua universitas di Turki (Yavuz \& Erbay, 2015). Haser dan Star mengemukakan latar belakang sekolah menengah tampak berpengaruh pada keyakinan peserta tentang pemahaman matematis. Peserta dari latar belakang sekolah yang paling kompetitif tampaknya memiliki keyakinan konsep pemahaman matematika yang lebih baik (Haser \& Star, 2002). Secara konkrit, penelitian yang menganalisis keyakinan tentang matematika menunjukkan bahwa siswa dalam memecahkan masalah berpikir bahwa belajar matematika memerlukan penghafalan (Raymond \& College, 1997; Uçar, 2010). Dari beberapa penelitian terdahulu yang telah dilakukan peneliti terdahulu belum menganalisis keyakinan calon guru terhadap kemampuan pemecahan masalah berdasarkan kemampuan matematika secara besamaan terutama terhadap calon guru sehingga peneliti melakukan penelitian yang berjudul Analisis Kemampuan Pemecahan Masalah dan Keyakinan Calon Guru dalam Menyelesaikan Soal Pemecahan Masalah.

Pada penelitian ini, kemampuan pemecahan masalah mahasiswa yang diteliti mencakup empat tahap pemecahan masalah berdasarkan pendapat Polya, yaitu memahami masalah, melakukan perencanaan, melakukan rencana dan pengecekan kembali (Polya, 1957). Keyakinan matematika adalah keyakinan mahasiswa dalam pemecahan masalah yang mencakup enam aspek keyakinan berdasarkan pendapat Kloosterman, yaitu keyakinan tentang waktu yang dibutuhkan untuk menyelesaikan masalah, keyakinan masalah tidak dapat diselesaikan dengan sederhana, tetapi langkah demi langkah, keyakinan tentang pemahaman konsep penting dalam pemecahan masalah, keyakinan tentang penting pemecahan masalah dalam matematika, keyakinan tentang usaha yang dapat meningkatkan kemampuan matematika, dan keyakinan tentang matematika berguna dalam kehidupan sehari-hari (Klossterman, 1992). Penelitian ini bertujuan untuk menganalisis kemampuan pemecahan masalah dan keyakinan calon guru dalam menyelesaikan soal pemecahan masalah karena hal ini berguna dalam proses pengembangan guru di masa akan datang, khususnya pengembangan calon guru yang dihasilkan oleh Program Studi Pendidikan Matematika UIN Ar-Raniry Banda Aceh.

\section{METODE}

Jenis penelitian yang digunakan dalam penelitian ini adalah penelitian deskriptif dengan pendekatan kualitatif. Penelitian ini untuk menganalisis tentang kemampuan pemecahan masalah mahasiswa Program Studi Pendidikan Matematika UIN Ar-Raniry Banda Aceh dalam menyelesaiakan soal matematika dan keyakinan mereka terhadap kemampuan pemecahan masalah mereka dalam menyelesaikan soal matematika.

Subjek penelitian ini adalah mahasiswa Program Studi Pendidikan Matematika Fakultas Tarbiyah dan Keguruan UIN Ar-Raniry Banda Aceh. Pemilihan subjek dimulai dengan terlebih dahulu memberikan tes kemampuan matematika yang dimodifikasi dan sudah divalidasi ahli sebelum digunakan. Tes Kemampuan Matematika tersebut diberikan kepada mahasiswa. Kemudian mahasiswa mengerjakan TKM tersebut. Setelah skor tes kemampuan matematika setiap mahasiswa dianalisis, mahasiswa dikelompokkan dalam tiga kemampuan matematika, yaitu tinggi, sedang, dan rendah.

Instrumen dalam penelitian ini adalah peneliti sebagai instrumen utama dengan menggunakan instrumen bantu berupa lembar tes kemampuan pemecahan masalah mahasiswa yang dibuat berdasarkan rubrik tes pemecahan masalah dengan materi perguruan tinggi meliputi Aljabar, Geometri, Trigonometri, dan Statistik yang divalidasi oleh dua orang dosen dari pendidikan Matematika FTK UIN Ar-Raniry Banda Aceh. Instrumen lainnya berupa angket keyakinan yang diadopsi dari angket yang telah divalidasi dan digunakan pada penelitian Kloosterman sehingga peneliti tidak memvalidasi kembali, tetapi peneliti hanya melakukan alih bahasa dengan bantuan Unit Pusat Bahasa Universitas Syiah Kuala.

Pengecekan keabsahan data dalam penelitian ini dilakukan dengan triangulasi. Adapun triangulasi yang digunakan dalam penelitian ini adalah triangulasi waktu, yaitu peneliti mengambil data dari subjek penelitian yang sama pada waktu atau situasi yang berbeda.

\section{HASIL}

Pengumpulan data diawali dengan tes terhadap semua calon subjek di ruang kuliah Multimedia prodi pendidikan Matematika UIN Ar-Raniry. Berdasarkan hasil tes tersebut diperoleh masing-masing satu subjek dengan kemampuan tinggi, sedang, dan rendah. Ketiga subjek masing-masing diberikan soal pemecahan masalah, angket keyakinan dan dilakukan wawancara secara mendalam untuk mengetahui kemampuan pemecahan masalah dan keyakinan masing-masing subjek. Pengecekan keabsahan data dilakukan dengan triangulasi waktu, pengumpulan data pada setiap subjek masing-masing dilakukan sebanyak dua kali pada waktu yang berbeda.

\section{Kemampuan Pemecahan Masalah Mahasiswa Kemampuan Tinggi dalam Menyelesaikan Soal Pemecahan Masalah}

Subjek berkemampuan tinggi dalam memahami masalah dapat menuliskan hal yang diketahui dan ditanyakan dengan benar dan lengkap. Pernyataan tersebut sebagaimana ditunjukkan pada gambar 1. 


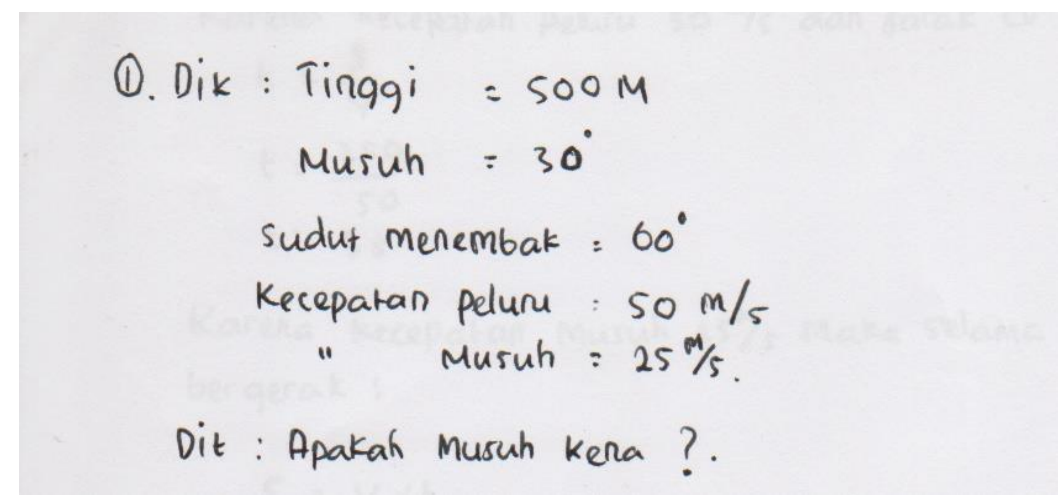

Gambar 1. Cuplikan subjek MKT menyelesaikan masalah 1

Subjek kemampuan tinggi juga mampu menceritakan kembali soal dengan bahasa sendiri dan menyebutkan hal yang diketahui dan ditanyakan secara baik dan benar. Seperti cuplikan wawancara berikut:

T1MKT5 : Dari soal ini tadi bang, diketahui ada sebuah menara yang tingginya $500 \mathrm{~m}$. Kemudian ada seorang penembak jitu di atasnya yang melihat musuh pada sudut kemiringan $30^{\circ}$.

Kemudian Penembak jitu tersebut menembakkan sebuah peluru dengan kecepatan $50 \mathrm{~m} / \mathrm{s}$ dengan sudut kemiringan tembak $60^{\circ}$.

P6 : Lainnya?

T1MKT6 : Lainnya yang ditanyakan bang, apakah peluru tersebut mengenai musuh jika musuh bergerak menjauhi menara dengan kecepatan $25 \mathrm{~m} / \mathrm{s}$ dengan menggunakan sepeda motor?

Subjek kemampuan tinggi mampu membuat dan menceritakan rencana penyelesaian dengan baik dan benar. Seperti pada cuplikan wawancara berikut:

T1MKT14 : Tadi pertama-pertama rencananya, saya membuat ilustrasi gambar dulu. Untuk memperjelas apa saja yang harus saya cari sebelum menghitung waktu tempuh peluru dan jarak tempuh musuh dengan waktu yang sama.

Subjek berkemampuan tinggi melaksanakan pemecahan masalah sesuai dengan langkah yang telah dibuat dengan menggunakan konsep dan prinsip matematika dengan benar. Pernyataan tersebut sebagaimana ditunjukkan pada gambar 2 dan 3 .

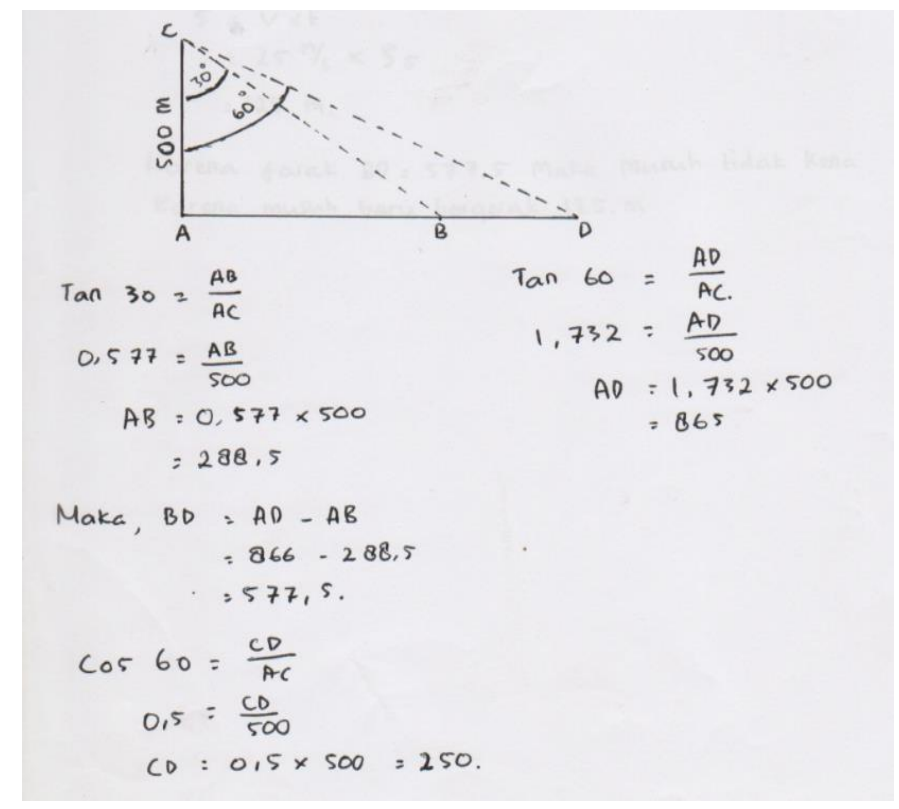

Gambar 2. Cuplikan subjek MKT menyelesaikan masalah 1 


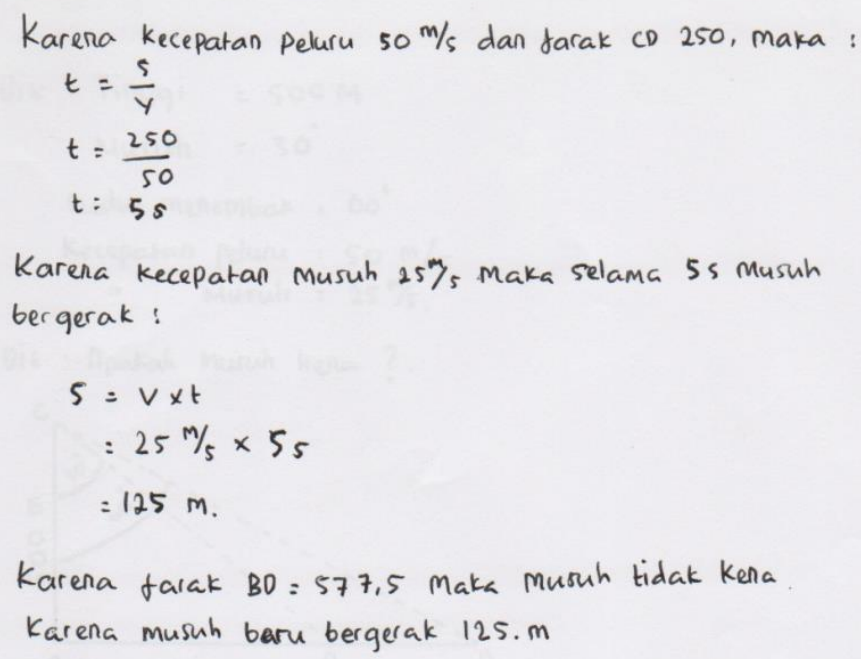

\section{Gambar 3. Cuplikan subjek MKT menyelesaikan masalah 1}

Subjek kemampuan tinggi mampu menjelaskan langkah-lagkah penyelesaian masalah dengan baik. Seperti pada cuplikan wawancara berikut:

T1MKT24 : Ini bang sisi di samping sudut di ketahui, sudutnya $30^{\circ}$, yang mau kita cari yang di depan sudut, jadi bisa kita pakek rumus tangen bang. Tangen $=$ sisi depan/sisi samping. Jadi, $\tan 30=\mathrm{BC} / \mathrm{AB}$, makanya dapat kek gini bang (sambil menunjukkan hasil kerja). Setelah cari yang ini bang, kita juga bisa pekek rumus ni lagi untuk cari sisi ini satu lagi bang Ini kek tadi juga bang, $\tan 60=$ sisi didepan ini di bagi sama sisi samping yang 500m ini bang. Ini kan bang z nya tinggal kita kurang saja y dengan $\mathrm{x}$ bang

P25

$$
\text { Terus? }
$$

T1MKT25 : Selanjutnya cari sisi ini bang sisi AD, ini sisi miring bang. Ini kita pakai Cos bang karena sisi miring, jadi bang cos $60=$ sisi miring dibagi sisi samping sudut, jadi dapatnya 250m bang. Terus, inikan dah dapat jaraknya 250m bang, sedangkan kecepatan peluru $50 \mathrm{~m} / \mathrm{s}$, jadi peluru butuh waktu $5 \mathrm{~s}$ untuk mencapai sasaran

P25 : Terus?

T1MKT25 : Terus ini kan bang, jaraknya tadi, yang $\mathrm{z}=577,5$. Jadi, karena waktu tadi $5 \mathrm{~s}$ dan musuh bergerak dengan kecepatan $25 \mathrm{~m} / \mathrm{s}$, maka musuh baru mencapai jarak $125 \mathrm{~m}$, jadi musuh gak kenak bang, karena sasaran peluru jauh jatuh di depan musuh.

Pada penyelesaian masalah 2 menunjukkan bahwa subjek kemampuan tinggi menuliskan hal yang diketahui dan ditanyakan dari soal dengan benar dan lengkap. Sebagaimana ditunjukkan pada gambar 4.

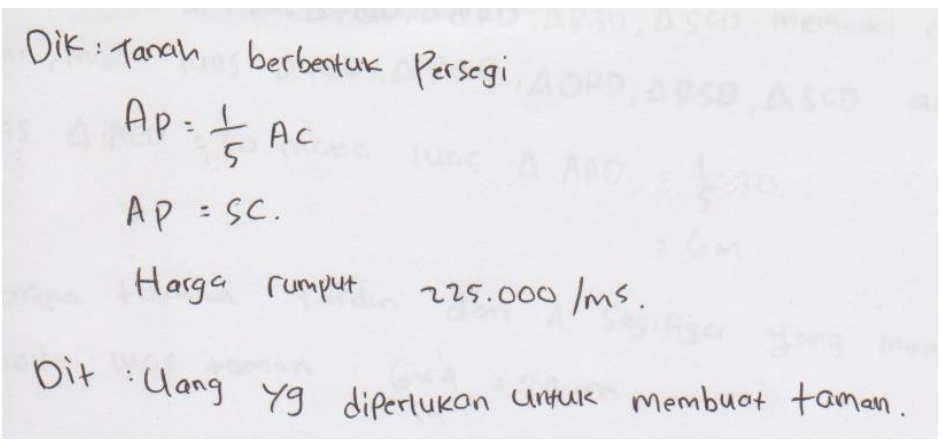

\section{Gambar 4. Cuplikan subjek MKT menyelesaikan masalah 2}

Subjek kemampuan tinggi juga mampu menceritakan kembali soalnya dengan menggunakan bahasanya sendiri dengan baik dan benar. Seperti pada cuplikan wawancara berikut: 
T1MKT5 : Ada sepetak tanah kosong di belakang hotel dengan panjang 12 meter dan lebar 5 meter. Tanah ini berbentuk persegi panjang. Manager hotel ingin membuat kolam renang yang berbentuk seperti ajar genjang kayaknya itu dengan ketentuan panjang AP itu sama dengan seperlima AC dan AP samadengan SC. Yang justru ditanyakan kalau pada bagian hijau itu ditanami rumput berapa biaya yang diperlukan manager hotel untuk taman rumput apabila harga satu meter persegi rumput adalah dua ratus dua puluh lima ribu rupiah.

Subjek kemampuan tinggi juga mampu menyebutkan hal yang diketahui dan ditanyakan dari soal dengan baik dan benar. Seperti pada cuplikan wawancara berikut:

P6 Dari soal ini (sambil menunjuk soal) informasi apa saja yang adek dapat untuk menyelesaikan soal?

T1MKT6 : Dari soal bang, diketahui ada tanah kosong di belakang hotel dengan bentuk persegi panjang dengan panjang $12 \mathrm{~m}$ dan lebar $5 \mathrm{~m}$.

P7 : Terus?

T1MKT7 : Di tanah itu rencananya mau dibuat kolam seperti gambar (sambil menunjuk gambar).trus, diketahui juga harga rumput dua ratus dua puluh lima ribu rupiah permeter kubik dan panjang AP sama dengan satuperlima AC dan AP samadengan SC. Yang ditanyakan besarnya biaya untuk membeli rumput taman.

Subjek kemampuan tinggi mampu membuat rencana penyelesaian dan melaksanakan pemecahan masalah sesuai dengan konsep dan prinsip matematika dengan lengkap dan benar. Sebagaimana ditunjukkan pada gambar 5 dan 6 .

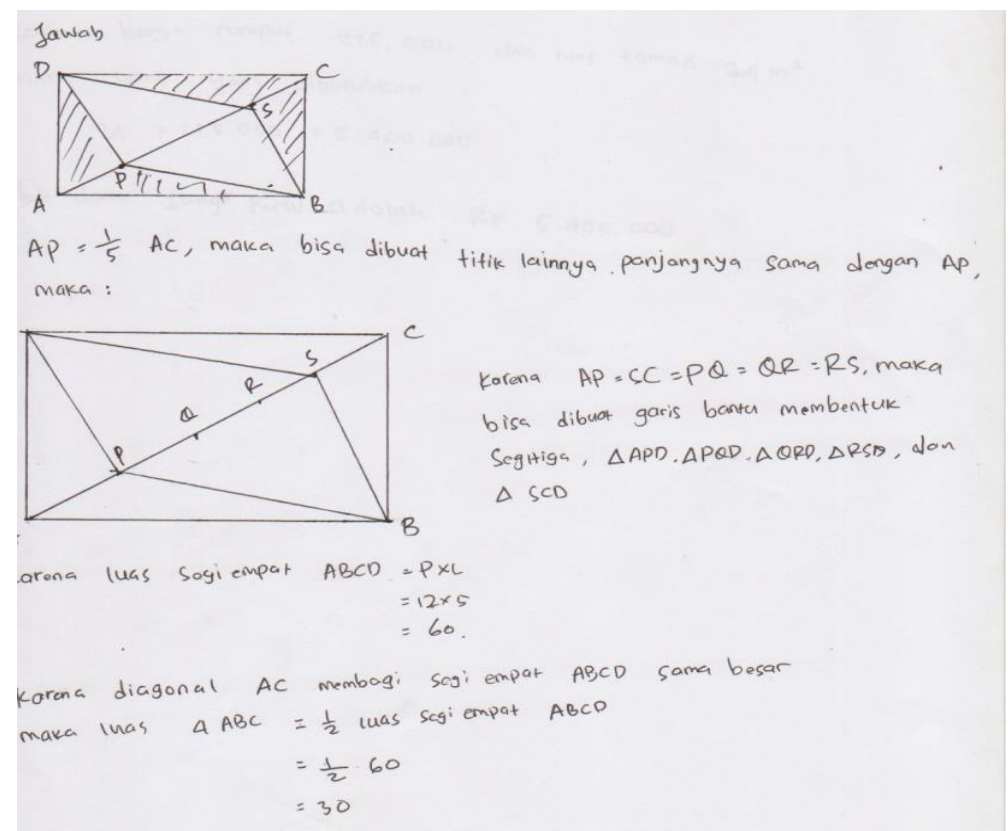

\section{Gambar 5. Cuplikan Subjek MKT menyelesaikan masalah 2}

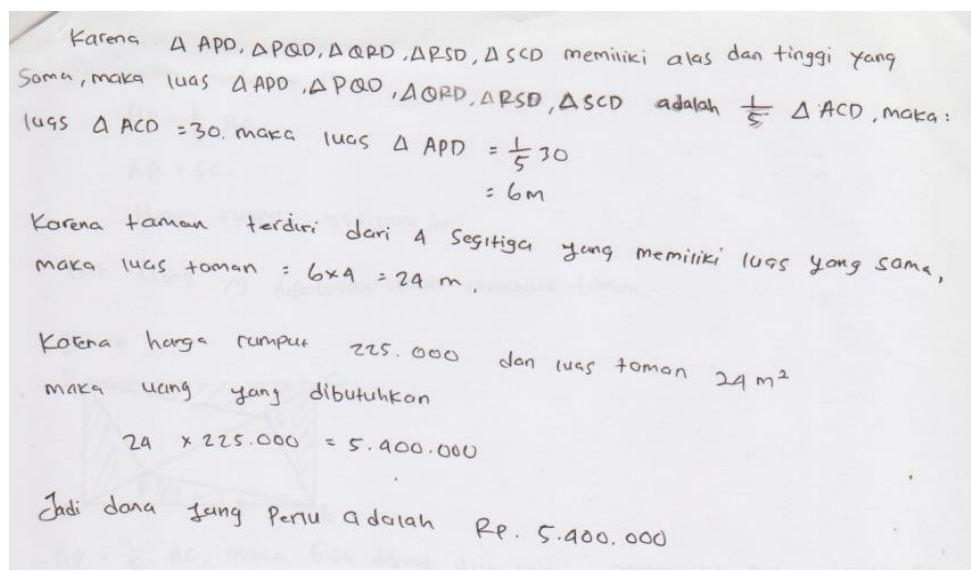

Gambar 6. Cuplikan Subjek MKT menyelesaikan masalah 2 
Subjek kemampuan tinggi mampu menjelaskan rencana dan langkah-langkah penyelesaian dari soal dengan baik. Seperti pada cuplikan wawancara berikut:

T2MKT22 : Tadi saya membuat gambar kembali untuk memudahkan saya dalam menyelesaikan soal ini kemudian saya membagi garis AC menjadi lima bagian yang sama panjang yaitu AP, PQ, QR, RS, dan SC.

P23 : Iya. Trus?

MKT23 : Kemudian saya menghitung luas persegi panjang berdasarkan panjang dan lebar yang diberikan sehingga diperoleh 60 meter persegi. Kemudian saya menghitung luas segitiga ACD dan ABC dari luas persegi panjang yang sudah dihitung sebelumnya. Saya dapat luas segitiga ACD dan ABC adalah 30.

$\mathrm{P} 24 \quad: \quad$ trus?

T2MKT24 : Nah dari 5 ruas garis yang sudah dibagi tadi dari masing-masing segitiga ACD dan ABC dapat dipecah menjadi segitiga kecil yaitu segitiga APD, PQD, QRD, RSD, SCD, ABP, PBQ, QBR, RBS, dan SBC. Kan tadi kelima alas segitiga ini sama panjang karena dibagi dari garis AC dan AC samadengan SC. Selain itu lima segitiga kecil yang segitiga ACD ini memiliki tinggi yang sama di titik D. Sehingga semua segitiga kecil ini (sambil menunjuk gambar) samaluasnya yaitu enam. dan sisi (sambil Menunjuk gambar) juga sama sehingga luas segitiga kecil sisi ini juga enam.

$\mathrm{P} 25$

T2MKT25 : Karena ada empat segitiga hijau jadi luas yang akan dibuat taman adalah enam dikali empat itu duapuluh empat.

P26 : Terus?

T2MKT26 : Dengan demikian, biaya yang diperlukan adalah dua puluh empat dikali dua ratus duapuluh lima ribu rupiah yaitu lima juta empat ratus ribu rupiah.

Subjek kemampuan tinggi juga memeriksa kembali jawabannya dengan mengecek hasil pekerjaannya dalam menyelesaikan soal dengan menunjuk pada setiap langkah. Seperti pada cuplikan wawancara berikut:

P29 : Berarti ini sudah benar ya menurut kamu?

T2MKT29 : $\quad$ Iya bang...

P30 : Memangnya dari mana kamu yakin?

T2MKT30 : Ini kan bang tadi sudah kita buat jadi lima...

P31 : Maksudnya?

T2MKT31 : Ini bang segitiganya ada 5 untuk setengah dari segi empat ini jadi bang, luas setengah segiempat ini sama dengan 5 segitiga yang kecil ini bang (sambil menunjuk gambar) jadi bang ini sesuai bang luasnya, luas segiempat ini $60 \mathrm{~m}^{2}$, sedangkan setengahnya $30 \mathrm{~m}^{2}$, luas segitiga kecil ini $6 \mathrm{~m}^{2}$, jadi sesuai bang, 5 segitiga sama dengan setengah segi empat atau 1 segi empat sama dengan 10 segitiga yang kecil ini bang (sambil menunjuk gambar).

Berdasarkan jawaban dari subjek kemampuan tinggi dalam menyelesaikan masalah 1 dan 2, diperoleh bahwa subjek MKT dalam menyelesaikan masalah dengan memahami masalah, subjek MKT menjelaskan hal yang diketahui dan ditanyakan dari soal dengan baik, subjek MKT membuat rencana sesuai dengan prosedur dan mengarah pada solusi yang benar, melaksanakan pemecahan masalah sesuai dengan rencana yang telah dibuat, subjek MKT juga melakukan pemeriksaan kembali jawaban dilakukan dengan mengecek hasil pekerjaannya dalam menyelesaikan soal dengan menunjuk pada setiap langkah dengan benar.

\section{Kemampuan Pemecahan Masalah Mahasiswa Kemampuan Sedang dalam Menyelesaikan Soal Pemecahan Masalah}

Subjek kemampuan sedang menuliskan yang diketahui dan ditanyakan dari soal dengan menggambarkan informasi yang diketahui dan ditanyakan dengan benar dan detail. Seperti pada gambar 7.

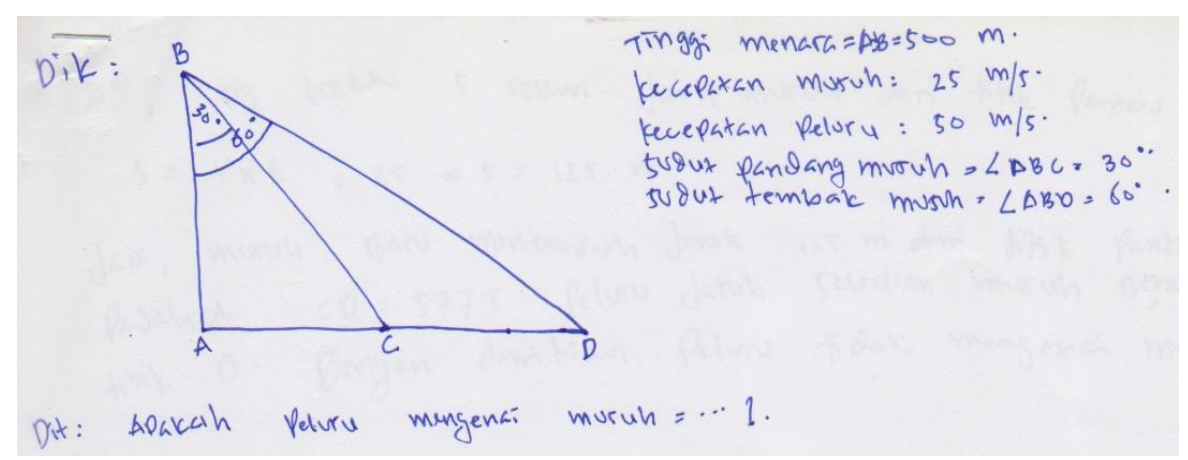

Gambar 7. Cuplikan Subjek MKS menyelesaikan masalah 1 
Subjek kemampuan sedang juga mampu menceritakan kembali hal yang diketahui dan ditanyakan oleh soal walaupun masih belum lengkap. Seperti pada cuplikan wawancara berikut:

T1MKS7 : Ini kan soalnya tu (membaca soal kembali) jadikan di situ ada diketahui tinggi menara tu 500 m, kemudian posisi si penembak itu pada 500m ketinggian,dan ketika melihat musuh itu pada kemiringan sudutnya $30^{\circ}$, kemudian disini diketahui lagi (Kembali membaca soal) jadi ada juga diketahui kemudian sipenembak ini menembakkan peluru pada kemiringan $60^{\circ}$, kemudian diketahui juga kecepatan si musuh tu $25 \mathrm{~m} / \mathrm{s}$ dan kecepatan peluru si penembak tu $50 \mathrm{~m} / \mathrm{s}$ dengan kemiringan $60^{\circ}$

P8 Oke, yang ditanyanya?

T1MKS8 : Yang ditanyanya disini (Sambil membaca kembali) bararti yang ditanya tu dengan kecepatan musuh tu $25 \mathrm{~m} / \mathrm{s}$ apakah dengan posisi penembak diketinggian menara $500 \mathrm{~m}$ dan sudut $60^{\circ}$ dan kecepatan pelurunya $50 \mathrm{~m} / \mathrm{s}$ akankah peluru itu mengenai musuh?

Subjek kemampuan sedang mampu membuat rencana dan melaksanakannya dengan menggambarkan setiap informasi yang diketahui dan informasi yang ditanyakan dengan benar namun masih belum lengkap. Seperti pada gambar 8 dan 9 .

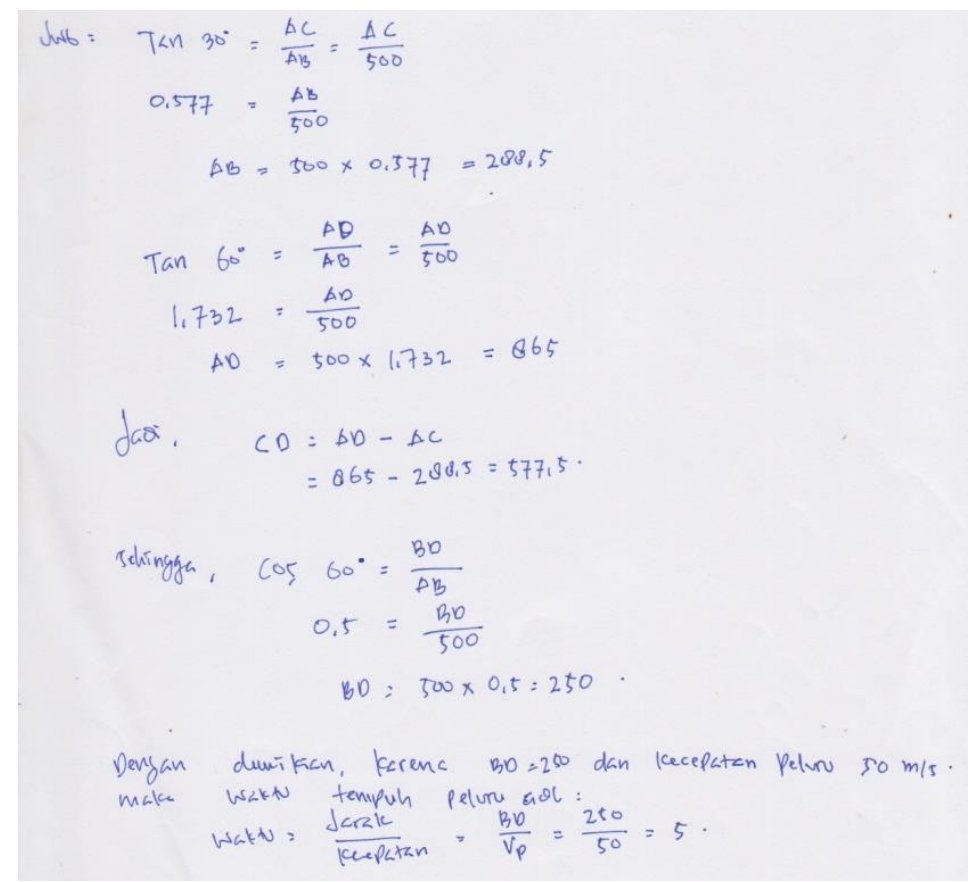

\section{Gambar 8. Cuplikan Subjek MKS menyelesaikan masalah 1}

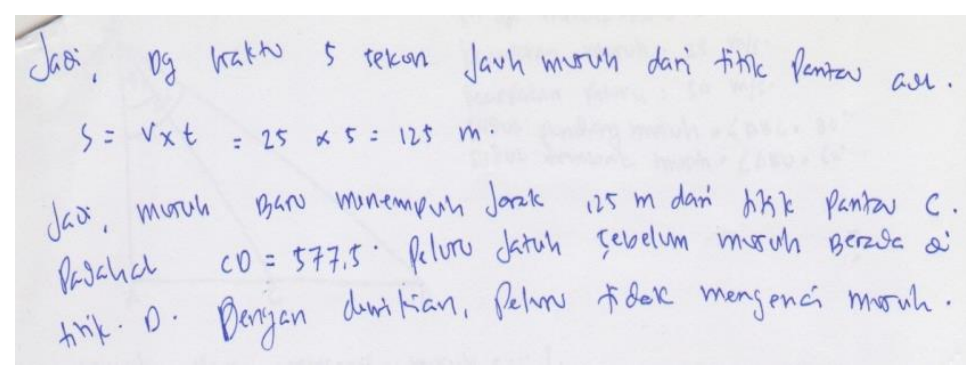

Gambar 9. Cuplikan Subjek MKS menyelesaikan masalah 1

Subjek kemampuan sedang mampu menjelaskan langkah-langkah jawaban yang telah dikerjakan dengan baik. Seperti pada cuplikan wawancara berikut:

T1MKS34 : Tadi kan, Pertama saya gambar dulu, ini menaranya, ini sudut musuhnya, ini sudut menembak $60^{\circ}$ (sambil menunjuk gambar) 


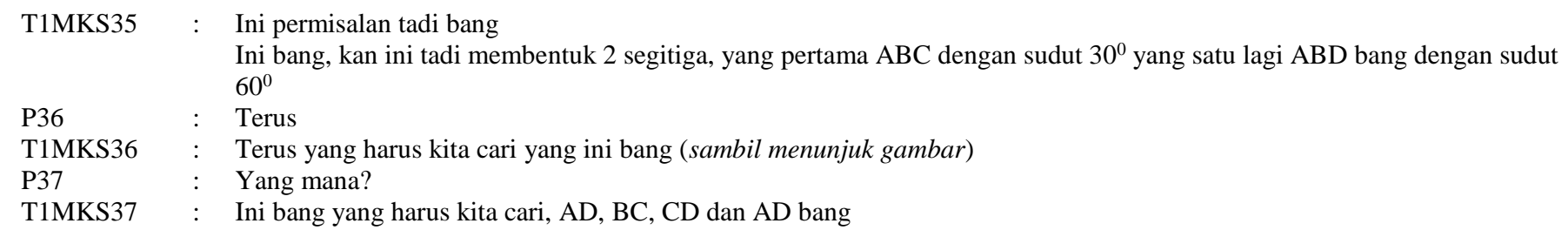

Subjek kemampuan sedang melakukan pemeriksaan kembali hasil pekerjaaan dengan mengecek hasil menyelesaikan masalah namun tidak dapat menjelaskan langkah-langkah secara terperinci. Seperti pada cuplikan wawancara berikut:

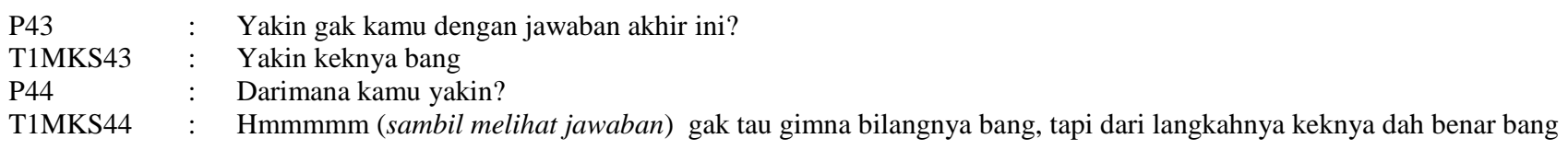

Pada penyelesaian masalah 2 menunjukkan subjek dengan kemampuan sedang mampu menuliskan hal yang diketahui dan ditanyakan dari soal dengan benar dan lengkap. Seperti pada gambar 10.

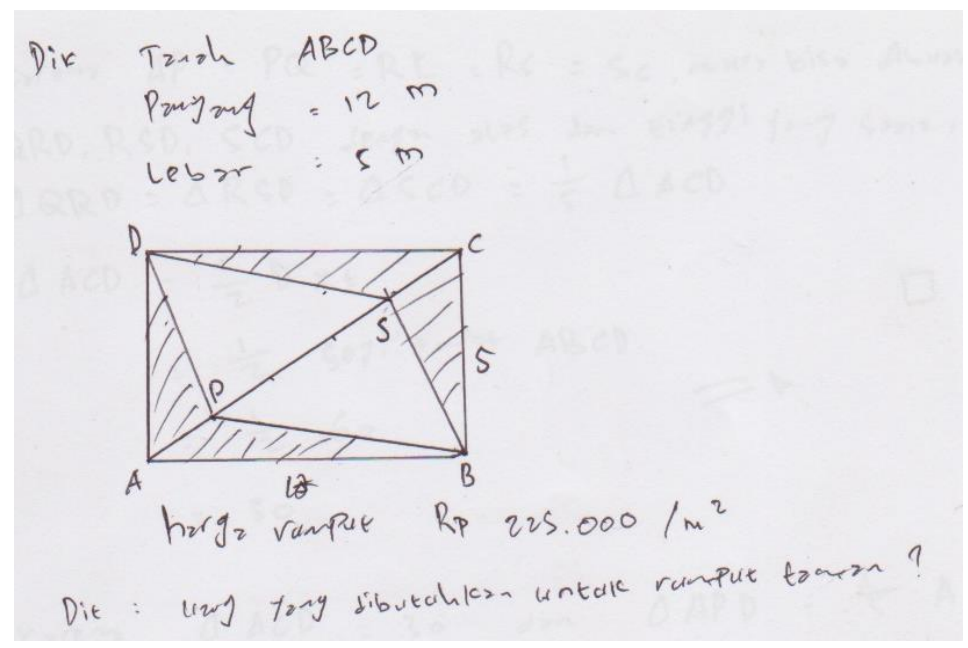

\section{Gambar 10. Cuplikan Subjek MKS menyelesaikan masalah 2}

Subjek kemampuan sedang mampu menceritakan kembali soal dengan menggunakan bahasanya sendiri dengan baik dan benar. Seperti pada cuplikan wawancara berikut:

T2MKS7 : Dari soal ini saya dapat beberapa hal yang diketahui ada sepetak tanah kosong dibelakang hotel dengan panjang 12 meter dan lebar 5 meter dan tanah ini berbentuk persegi panjang.

P8

Oke, yang ditanyanya?

T2MKS8

: Trus

T2MKS9 : Sudah bisa

P10 : Ada gak informasi lainnya

T2MKS10 : Gak ada

Subjek kemampuan sedang mampu membuat rencana dan melaksanakan pemecahan masalah sesuai dengan rencana yang telah dibuat dengan benar dan lengkap. Seperti pada gambar 11 dan 12. 


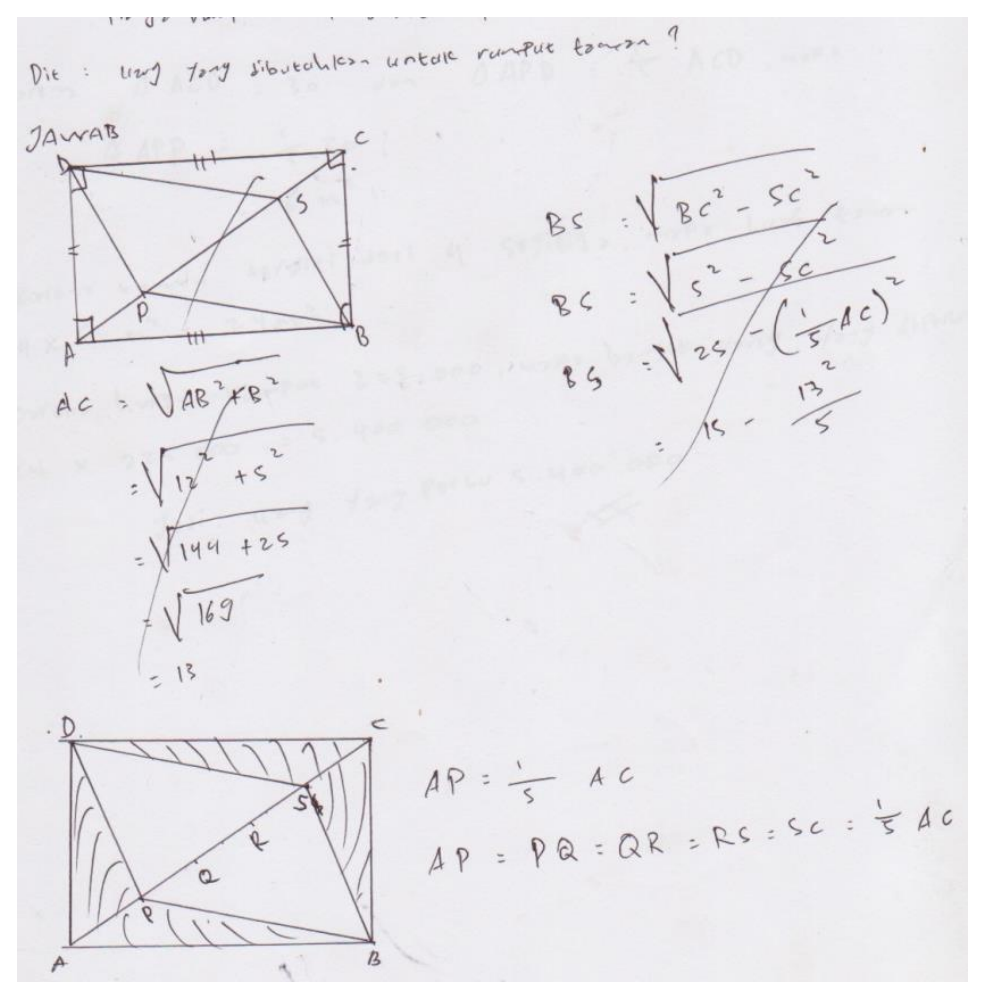

\section{Gambar 11. Cuplikan Subjek MKS menyelesaikan masalah 2}

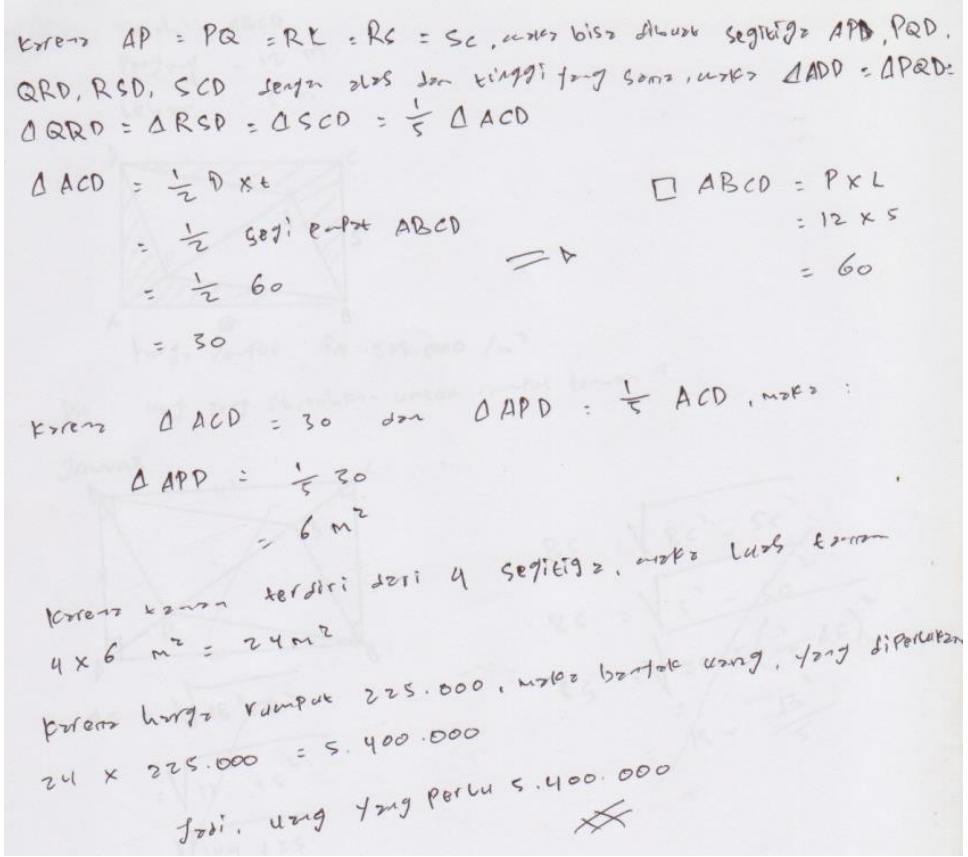

Gambar 12. Cuplikan Subjek MKS menyelesaikan masalah 2

Subjek kemampuan sedang mampu menjelaskan langkah-langkah jawaban yang telah dikerjakan dengan baik akan tetapi masih belum lengkap. Seperti pada cuplikan wawancara berikut:

T2MKS18 : Saya buat gambar dulu tadi bang

P19 : Maksudnya?

T2MKS19 : Ini kan bang (sambil menunjuk gambar) saya buat titik-titik dulu tadi,

P20 : Trus? 
T2MKS20 : Karena disoal tadi diiketahui bahwa AP sama dengan seperlima AC maka dapat dikatakan AC bisa dibagi lima. P21 : Trus?

T2MKS21 : Dengan alas garis AC yang dibagi lima Inikan (sambil menunjuk gambar) membentuk segitiga-segitiga kecil baru. Dan segitiga kecil baru ini memiliki luas yang sama antara satu dengan lainnya. Kita tahu disini bahwa lima segitiga kecil membentuk segitiga besar ACD ini (sambil menunjuk gambar). Ini kan bisa kita cari segitiga hijau kecil ini semua (sambil menunjuk gambar)

P22 : Kenapa bisa luas segitiga kecil ini sama kelimanya?

T2MKS22 : Iya bang. Inikan karena alasnya sama dan tingginya sama rumus luas segitiga kan setenagh alas kali tinggi bang. Jadi kalau alasnya sama dan tingginya sama maka luas segitiga menjadi sama.

Subjek kemampuan sedang memeriksa kembali jawabannya dengan mengecek hasil pekerjaannya dalam menyelesaikan soal akan tetapi tidak bisa menjelskan langkah-langkah pemeriksaan dengan rinci. Seperti pada cuplikan wawancara berikut:

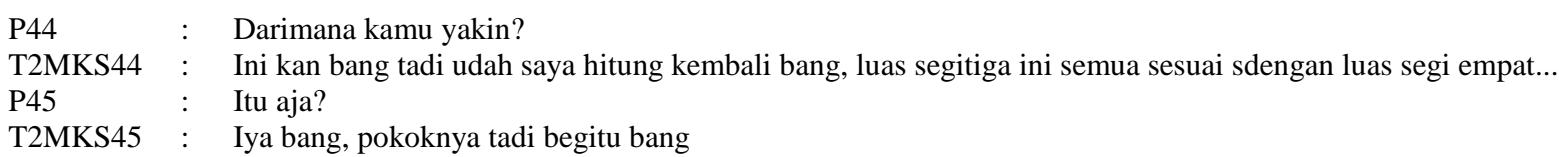

Berdasarkan jawaban dari subjek kemampuan sedang dalam menyelesaikan masalah 1 dan 2, diperoleh bahwa subjek MKS memahami masalah dengan lengkap, membuat rencana yang benar, tetapi belum lengkap dalam hal menggambarkan setiap informasi yang diketahui dan yang ditanyakan. Subjek MKS juga melakukan proses perhitungan benar sehingga mendapatkan hasil yang benar namun masih terdapat beberapa kesalahan. Subjek MKS dalam menjelaskan langkah-langkah jawaban yang telah dikerjakan masih belum lancar sehingga subjek tidak dapat menjelaskan pemeriksaan kembali dengan lancar.

\section{Kemampuan Pemecahan Masalah Mahasiswa Kemampuan Rendah dalam Menyelesaikan Soal Pemecahan Masalah}

Subjek kemampuan rendah menuliskan hal yang diketahui dengan lengkap dan benar namun keliru dalam menuliskan unsur yang ditanyakan. Seperti pada gambar 13.

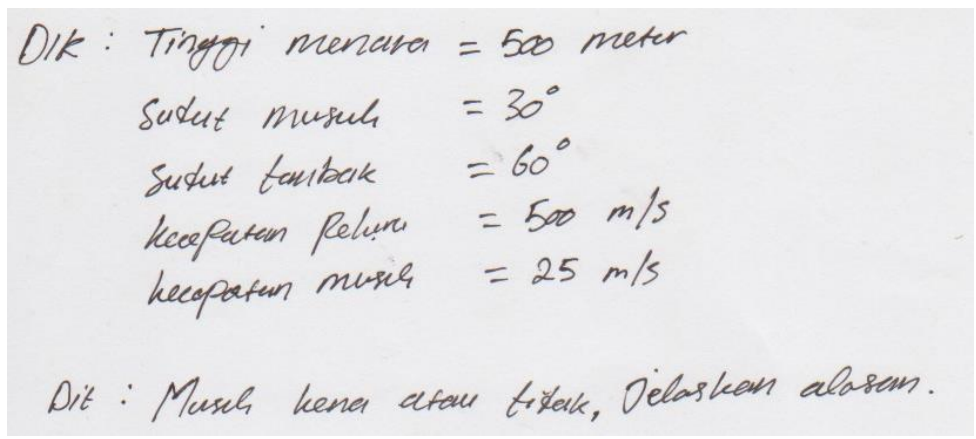

Gambar 13. Cuplikan Subjek MKR menyelesaikan masalah 1

Subjek kemampuan rendah menceritakan kembali unsur yang diketahui dan ditanyakan walaupun masih belum lengkap. Seperti pada cuplikan wawancara berikut:

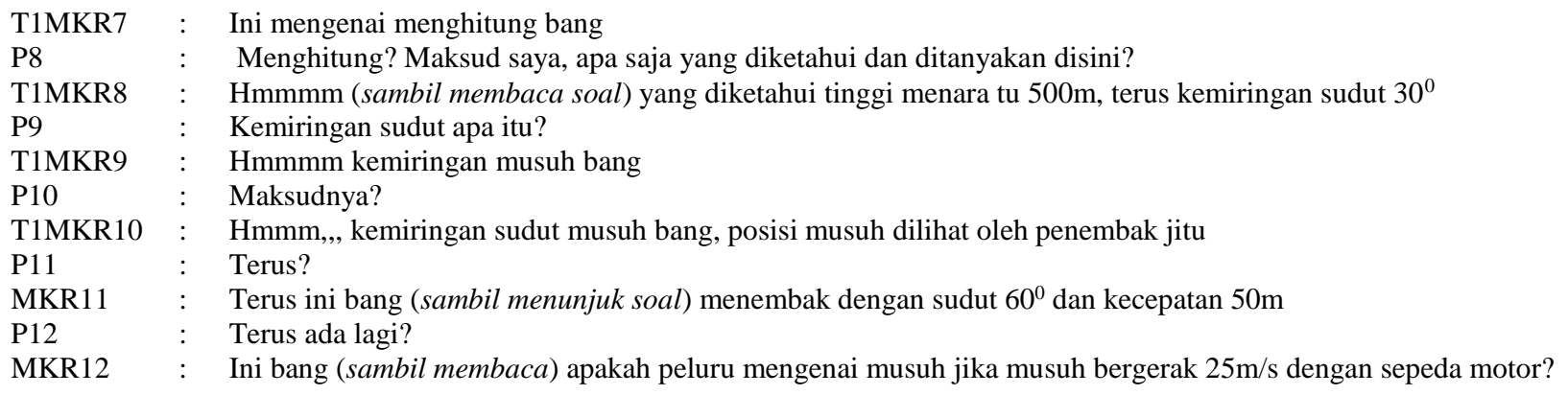

Subjek kemampuan rendah merencanakan dan melaksanakan rencana dengan lancar tetapi konsepnya salah. Seperti pada gambar 14 . 


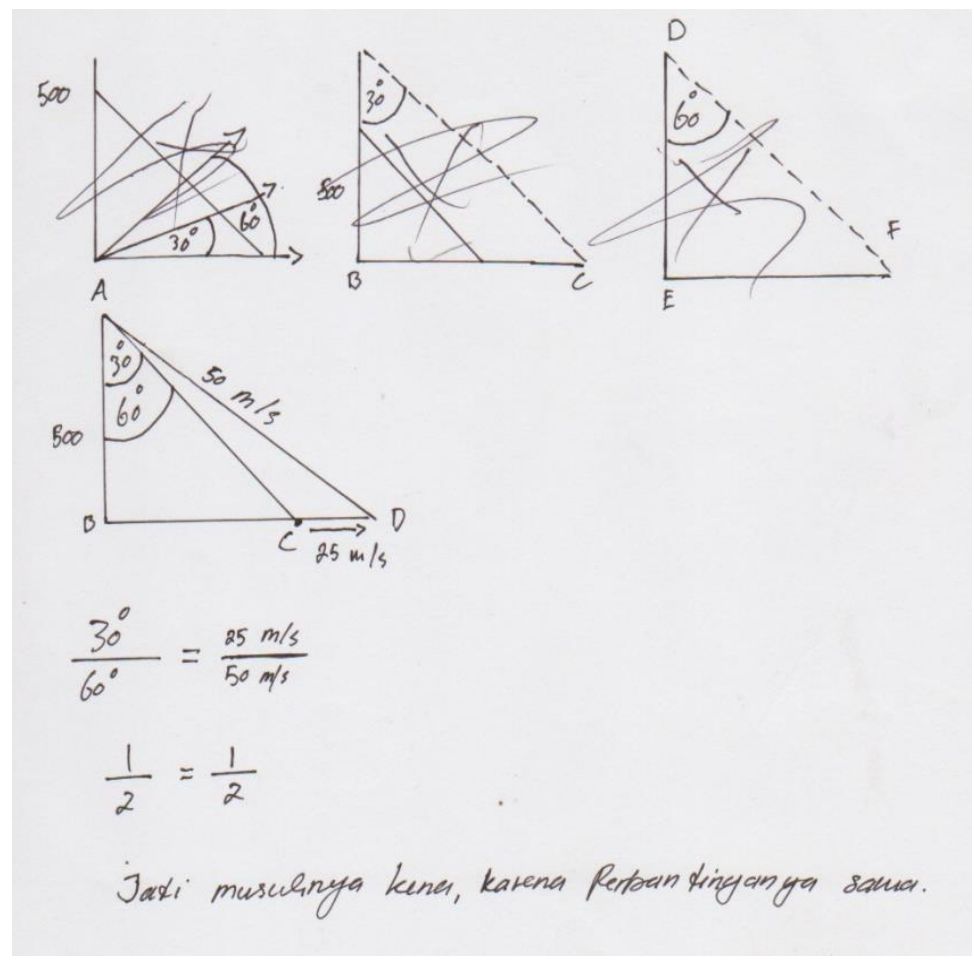

\section{Gambar 14. Cuplikan Subjek MKR menyelesaikan masalah 1}

Subjek kemampuan rendah menjelaskan rencana penyelesaian dari soal dengan tidak lancar. Seperti pada cuplikan wawancara berikut:

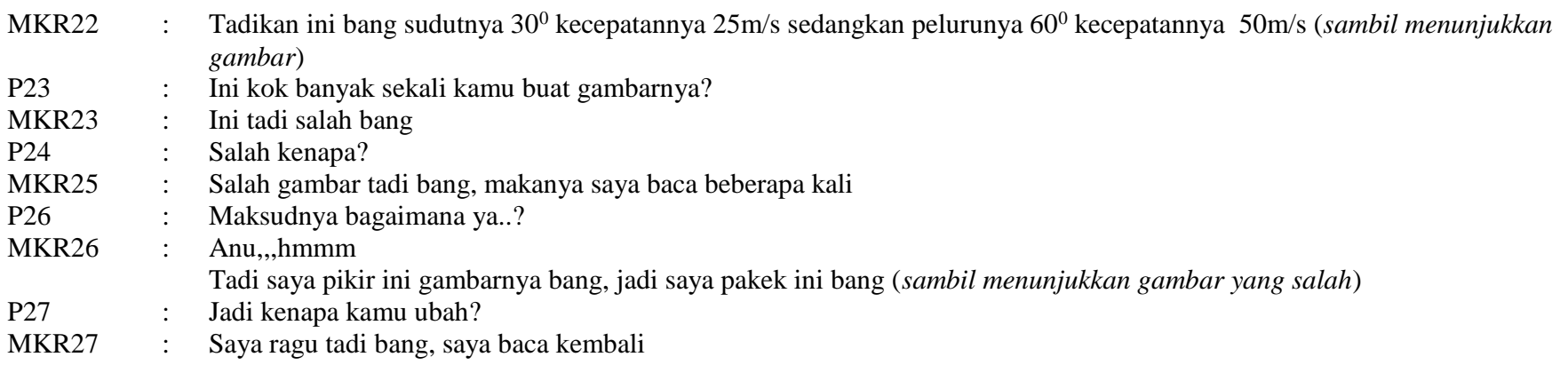

Subjek MKR memeriksa kembali jawaban namun tidak bisa menjelaskan alasan dari setiap langkah penyelesaian masalah yang telah dibuat. Seperti pada cuplikan wawancara berikut:

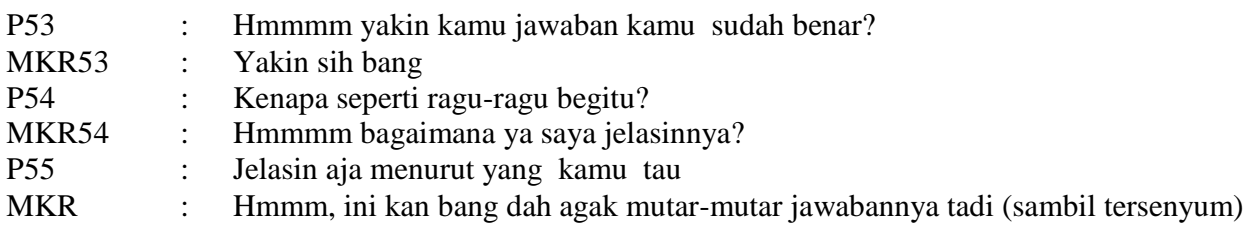

Pada penyelesaian masalah 2 menunjukkan subjek dengan kemampuan rendah mampu menuliskan hal yang diketahui dan ditanyakan dengan benar dan lengkap. Seperti pada gambar 15 . 


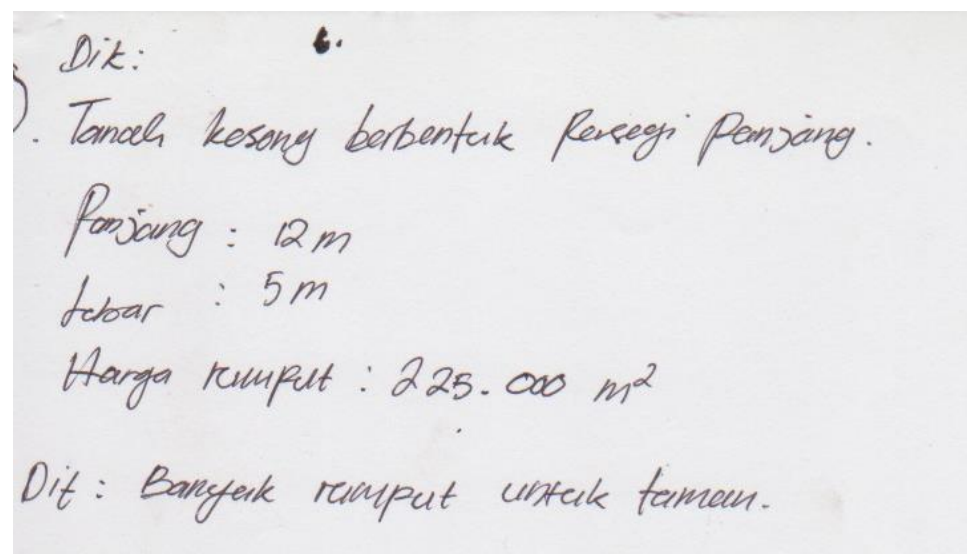

\section{Gambar 15. Cuplikan subjek MKR menyelesaikan masalah 2}

Subjek kemampuan rendah mampu menyebutkan dan menceritakan yang diketahui dan ditanyakan dengan benar. Seperti pada cuplikan wawancara berikut:

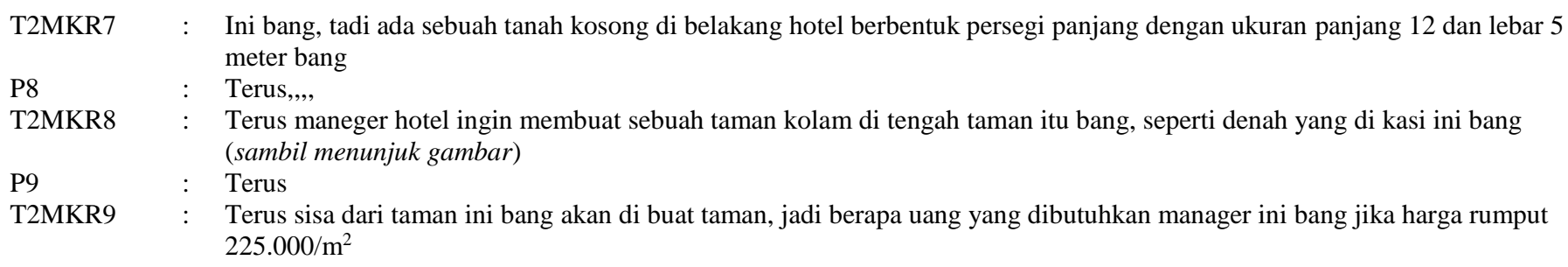

Subjek kemampuan rendah melaksanakan rencana dengan lancar tetapi konsepnya salah. Seperti pada gambar 16.

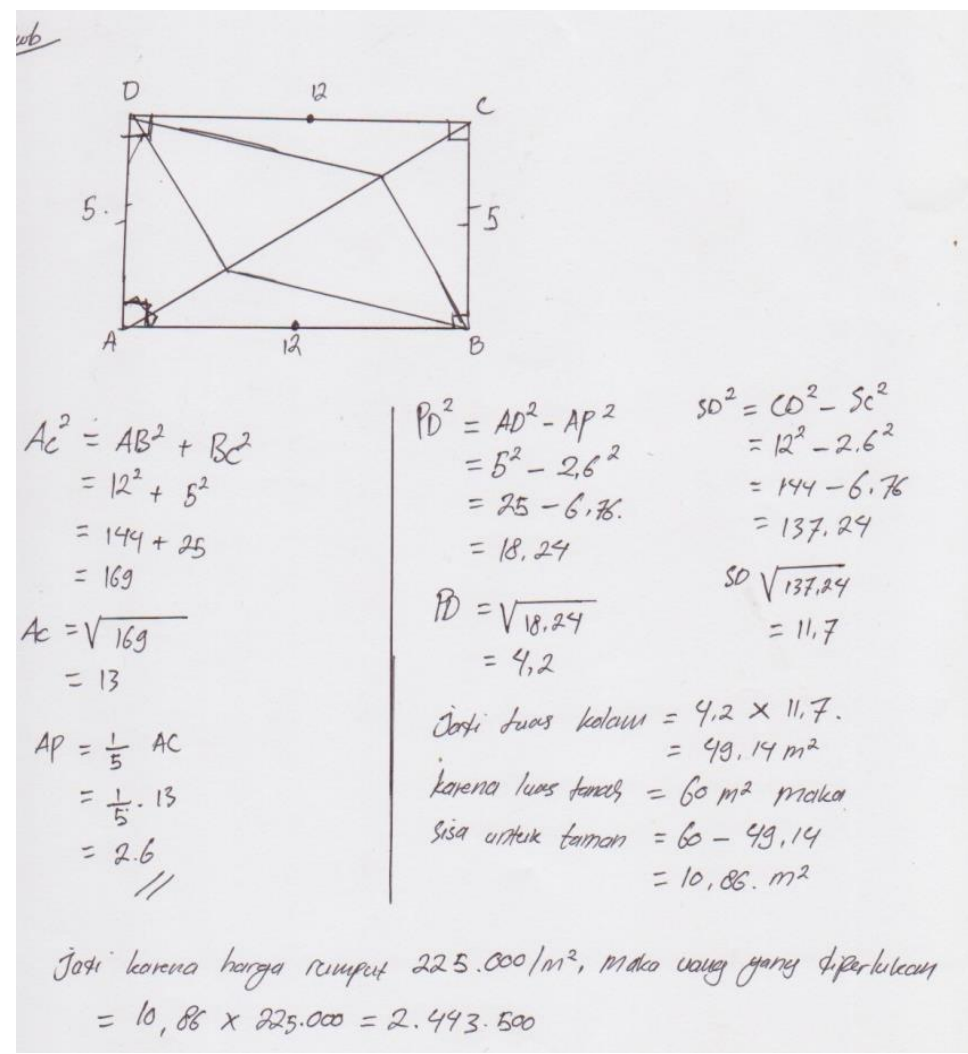

Gambar 16. Cuplikan subjek MKR menyelesaikan masalah 2 
Subjek kemampuan rendah menjelaskan langkah-langkah jawaban yang telah dikerjakan namun konsep yang digunakan masih salah. Seperti pada cuplikan wawancara berikut:

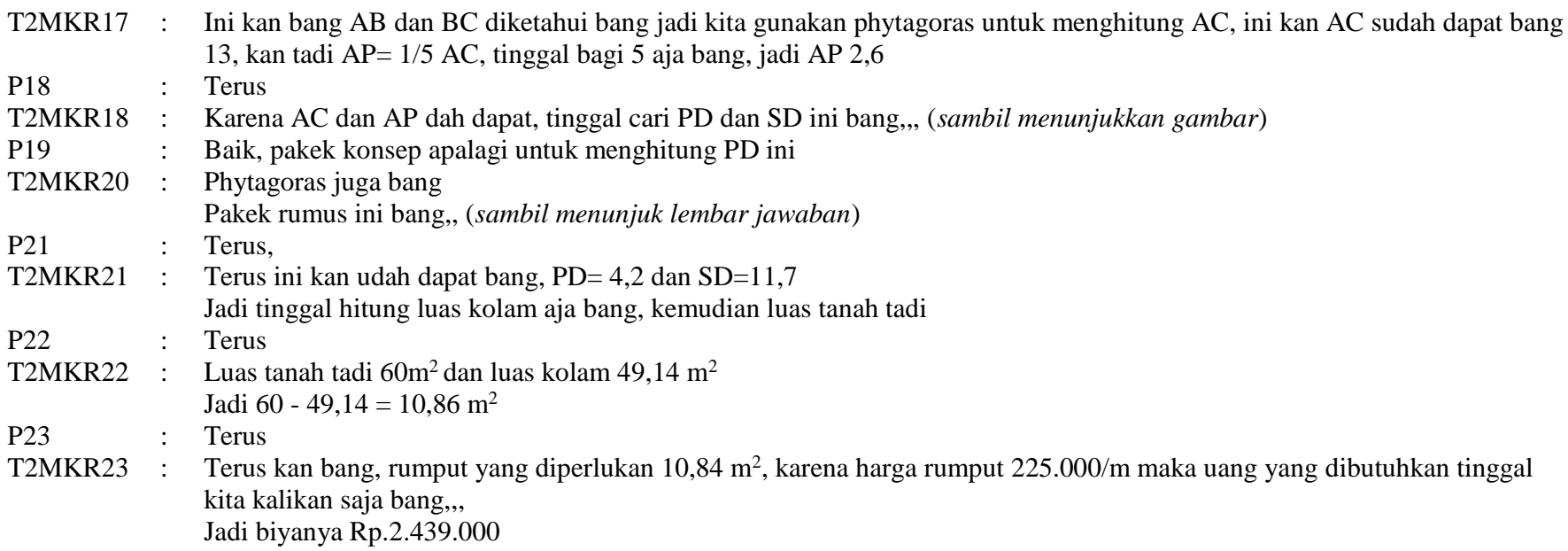

Subjek kemampuan rendah memeriksa kembali hasil penyelesaian dengan membaca kembali jawaban yang diselesaikan tetapi tidak menjelaskan secara rinci langkah-langkahnya. Seperti pada cuplikan wawancara berikut:

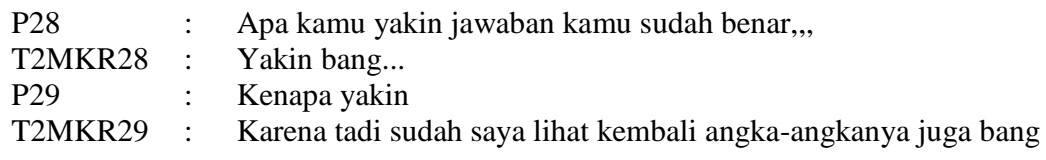

Berdasarkan jawaban dari subjek kemampuan rendah dalam menyelesaikan masalah 1 dan 2, diperoleh bahwa subjek MKR memahami masalah dengan lengkap dan menceritakan kembali dengan melihat pada naskah soal serta menyebutkan hal yang diketahui dan ditanyakan dari soal dengan baik dan benar. Subjek MKR membuat rencana namun salah dalam memilih konsep sehingga memperoleh hasil yang salah. Subjek MKR menjelaskan rencana penyelesaian dari soal tidak lancar dan belum lengkap. Subjek MKR memeriksa kembali jawaban dilakukan namun tidak bisa menjelaskan alasan dari setiap pemeriksaan penyelesaian masalah yang telah dibuat dengan baik dan benar.

\section{Keyakinan Mahasiswa Kemampuan Tinggi dalam Menyelesaikan Soal Pemecahan Masalah}

Berdasarkan angket keyakinan diperoleh kesimpulan bahwa keyakinan subjek kemampuan tinggi yakin membutuhkan waktu untuk menyelesaikan soal-soal pemecaham masalah, mulai dari membaca soal, memahami dan menentukan konsep. Subjek kemampuan tinggi yakin dalam menyelesaikan soal pemecahan masalah dilakukan tahap demi tahap, mulai dari membuat diketahui, gambar, dan langkah yang dilakukan dengan meghitung tahapan-tahapanya sebelum menghitung tahapan akhir. Subjek kemampuan tinggi yakin membutuhkan pemahaman konsep dalam menyelesaikan soal pemecahan masalah, tanpa pemahaman konsep, soal tidak bisa dikerjakan dengan benar. Subjek kemampuan tinggi yakin akan pentingnya pemecahan masalah dalam belajar matematika. Subjek kemampuan tinggi yakin dengan sering menyelesaikan soal pemecahan masalah, maka akan mengasah kemampuan pemecahan masalah. Subjek kemampuan tinggi juga yakin tentang kegunaan pemecahan masalah dalam kehidupan sehari-hari

\section{Keyakinan Mahasiswa Kemampuan Sedang dalam Menyelesaikan Soal Pemecahan Masalah}

Berdasarkan angket keyakinan diperoleh kesimpulan bahwa keyakinan subjek kemampuan sedang yakin membutuhkan waktu untuk menyelesaikan soal-soal pemecahan masalah, mulai dari membaca soal, memahami dan menentukan konsep, bahkan membuat gambar sebanyak dua kali. Subjek kemampuan sedang yakin menyelesaikan soal pemecahan masalah tahap demi tahap, mulai dari membuat diketahui, gambar, dan langkah yang dilakukan dengan menghitung tahapan-tahapanya sebelum menghitung tahapan akhir. Subjek kemampuan sedang yakin memerlukan pemahaman konsep dalam pemecahan masalah, apabila konsep tidak diketahui, maka langkah atau hasil akhir akan salah. Subjek kemampuan sedang yakin tentang pentingnya kemampuan pemecahan masalah dalam matematika sehingga memudahkan dalam penyelesaian soal-soal dalam matematika. Subjek kemampuan sedang meyakini ada beberapa usaha yang bisa dilakukan untuk meningkatkan kemampuan pemecahan masalah, salah satunya dengan sering mengerjakan soal-soal pemecahan masalah atau sering mempejari konsep-konsep dalam matematika. Subjek kemampuan sedang yakin, jika kemampuan pemecahan masalah sangat berguna dalam kehidupan sehari-hari dalam menghadapi masalah. 


\section{Keyakinan Mahasiswa Kemampuan Rendah dalam Menyelesaikan Soal Pemecahan Masalah}

Berdasarkan angket keyakinan diperoleh kesimpulan bahwa keyakinan subjek kemampuan rendah yakin membutuhkan waktu yang lama (hampir satu jam) dalam menyelesaikan soal pemecahan masalah. Subjek kemampuan rendah yakin menyelesaikan masalah dengan beberapa langkah, mulai dari menggambar bahkan ada beberapa gambar yang dibuat, dan menentukan konsep beberapa kali. Subjek kemampuan rendah yakin memerlukan pemahaman konsep dalam pemecahan masalah, apabila konsep tidak diketahui, maka langkah atau hasil akhir akan salah dan harus di ulang. Subjek kemampuan rendah yakin tentang pentingnya kemampuan pemecahan masalah dalam matematika sehingga memudahkan dalam penyelesaian soal-soal dalam matematika. Subjek kemampuan rendah yakni kemampuan pemecahan masalah dapat ditingkatkan dengan belajar dan mengerjakan latihan. Subjek kemampuan rendah juga yakin tentang pentingnya kemampuan pemecahan masalah dalam kehidupan sehari-hari.

\section{PEMBAHASAN}

Berdasarkan hasil pemaparan data di atas terlihat persamaan dan perbedaan deskripsi yang diperoleh oleh masingmasing subjek penelitian. Subjek MKT dapat menuliskan dan mendeskripsikan dengan detail dan lengkap setiap hal yang diketahui dan ditanyakan, merencanakan setiap hal dengan detail, melaksanakan sesuai dengan rencana dan konsep pembelajaran dengan benar, melaksanakan penyelesaian masalah dengan baik dan sesuai dengan rencana dan menggunakan aturan atau konsep matematika dengan benar dan mengecek kembali hasil pekerjaan dengan menunjuk setiap langkah yang telah dilaksanakan dengan baik dan jelas. Subjek MKS dapat menuliskan dan mendeskripsikan dengan detail dan lengkap setiap hal yang diketahui dan ditanyakan, merencanakan setiap hal dengan detail, merencanakan penyelesaian masalah dengan detil tetapi masih kurang lancar, melaksanakan pemecahan masalah dengan melakukan perhitungan sesuai dengan rencana yang ada namun masih terdapat beberapa kesalahan, mengecek hasil pekerjaannya dalam menyelesaikan soal dengan menunjuk pada setiap langkah dari penyelesaian masalah yang telah dikerjakan dengan baik namun masih belum lengkap dan runtut. Subjek MKR menuliskan dan menceritakan semua hal yang diketahui dan ditanyakan tetapi masih belum lengkap, merencanakan dan melaksanakan pemecahan masalah sesuai dengan prosedur tetapi konsep yang digunakan masih salah, pemeriksaan yang dilakukan tidak tuntas melalui pengecekan pada hasil jawaban yang diperoleh pengecekan pemeriksaan tidak tuntas serta tidak bisa menjelaskan alasan dari setiap pemeriksaan penyelesaian masalah yang telah dibuat.

Berdasarkan jawaban, terdapat kesamaan dalam memahami masalah antara subjek kemampuan tinggi dan subjek kemampuan sedang yaitu mengidentifikasi hal yang diketahui dan ditanyakan secara lisan, menuliskan informasi yang diketahui dan ditanyakan dengan benar. Sementara itu, subjek dengan kemampuan rendah memahami masalah dengan mengidentifikasi informasi yang diketahui dan ditanyakan namum masih tidak lengkap. Dalam menyusun rencana penyelesaian masalah, dan melaksanakan rencana penyelesaian masalah, subjek kemampuan tinggi dan subjek kemampuan sedang memiliki kesamaan dalam membuat rancangan, akan tetapi subjek dengan kemampuan tinggi membuat rencana yang akan digunakan, sedangkan subjek kemampuan sedang harus mencoba membuat beberapa opsi sebelum memilih rencana yang paling cocok. Sedangkan subjek kemampuan rendah dalam merencanakan penyelesaian masalah salah dalam memlilih konsep.

Secara umum, ketiga subjek dalam penelitian ini melakukan prosedur yang sesuai dengan langkah-langkah Polya, akan tetapi lama waktu, perencanaan, dan konsep yang digunakan yang berbeda terutama terlihat pada subjek dengan kemampuan rendah. Ketiga subjek juga membutuhkan beberapa kali membaca soal agar memahami masalah, dimulai dengan subjek kemampuan tinggi membaca soal sebanyak dua atau tiga kali, subjek kemampuan rendah membaca tiga sampai lima kali dan subjek dengan kemampuan rendah membaca sebanyak tujuh kali. Hal ini sejalan dengan pendapat Rosanti yang menyatakan bahwa melakukan pembacaan pada masalah secara berulang-ulang dilakukan untuk memahami masalah yang diberikan sehingga subjek memahami permasalah yang ada dan bisa merencanakan apasaja langkah-langkah selanjutnya (Rosanti, 2014).

Perencanaan dan pelaksanaan pemecahan masalah subjek kemampuan tinggi dan subjek kemampuan sedang dilakukan dengan baik dan benar, sekalipun subjek dengan kemampuan sedang membuat beberapa rencana sebelum memutuskan rencana yang digunakan. Sedangkan subjek dengan kemampuan rendah juga membuat beberapa perencanaan dan melakukan pelaksanaan pemecahan masalah, akan tetapi konsep yang digunakan keliru atau salah. Hal ini sesuai dengan pendapat Yurizka yang menyatakan bahwa subjek berkemampuan tinggi mempunyai kemampuan yang lebih baik dalam pemahaman konsep matematika daripada subjek yang lain (Yurizka, 2012). Sedangkan berdasarkan penelitian yang dilakukan oleh Nirmalitasari diketahui bahwa subjek berkemampuan rendah dalam merencanakan pemecahan masalah berada pada kategori cukup (Nirmalitasari, 2009). Hal tersebut dikarenakan subjek belum pernah menemui masalah seperti itu dan masih ragu-ragu dalam menentukan rencana pemecahan masalah.

Pada tahap memeriksa kembali, mahasiswa dengan kemampuan tinggi menjelaskan setiap langkah pemerikasaan dengan benar dan rinci. Subjek kemampuan sedang tidak dapat menjelaskan setiap langkah penyelesaian dengan teliti namun langkah penyelesaian benar, sedangkan subjek dengan kemampuan rendah tidak bisa menjelaskan dengan benar karena konsep yang digunakan masih keliru. Hal ini sejalan dengan penelitian yang dilakukan oleh Nahdataeni yang menyatakan bahwa untuk memeriksa kembali jawaban yang diperoleh, subjek harus mencari kesesuaian antara penyelesaian dengan hal yang diketahui dengan cara mengembalikan hasil yang diperoleh ke hal yang diketahui (Nahdataeni, 2013). 
Berdasarkan uraian pemecahan masalah seperti tersebut di atas, dapat disimpulkan bahwa mahasiswa yang memiliki kemampuan pemecahan masalah matematis yang baik jika ia telah mampu (1) memahami masalah, (2) memilih strategi yang tepat untuk menyelesaikan masalah, (3) menyelesaikan masalah dengan benar dan sistematis, dan (4) memeriksa sendiri ketepatan strategi yang dipilihnya dan kebenaran penyelesaian masalah yang didapatkannya. Namun, ada juga subjek yang memiliki kendala-kendala tertentu yang tidak hanya menyangkut prosedur, langkah atau konsepnya.

Beberapa kendala yang mungkin ditemui seseorang dalam menyelesaikan masalah antara lain menyangkut salah interpretasi, ukuran masalah, dan motivasi. Terkait dengan kendala salah interpretasi, besar kemungkinan hal ini dikarenakan ketidakmampuan subjek menganalisis masalah, kesalahan subjek memilih konsep, ketidakjelasan deskripsi masalahnya, kerancuan bahasa yang digunakan, atau kekurangtepatan penggunaan istilah, notasi, gambar, tabel atau grafik yang digunakan.

\section{Keyakinan Mahasiswa}

Berdasarkan hasil paparan di atas terlihat bahwa keyakinan mahasiswa dalam menyelesaikan soal pemecahan masalah relatif sama, semua subjek membutuhkan waktu yang lama dalam meyelesaikan soal pemecahan masalah, mereka yakin jika soal pemecahan masalah itu harus diselesaikan langkah perlangkah sesuai dengan prosedur yang ada, ketiga subjek yakin akan pentingnya konsep dalam menyelesaikan soal pemecahan masalah, mereka juga yakin bahwa pemecahan masalah sangat penting dalam pembelajaran matematika, mereka yakin bahwa terdapat usaha-usaha untuk meningkatkan kemampuan pemecahan masalah dan ketiga subjek juga yakin bahwa pemecahan masalah penting dalam kehidupan sehari-hari.

Berdasarkan pemaparan hasil di atas diketahui bahwa keyakinan mahasiswa dengan kemampuan matematika tinggi membutuhkan waktu untuk menyelesaikan permasalahan, memahami dan menentukan konsep dan langkah. Mahasiswa dengan kemampuan tinggi menyelesaikan soal pemecahan masalah tahap demi tahap, mulai dari membuat diketahui, gambar, dan langkah yang dilakukan dengan meghitung tahapan-tahapanya. Hal ini juga diungkap oleh Muhtarom pada keyakinan jenis ke-1 bahwa subjek meyakini bahwa masalah harus diselesaikan dengan mengikuti langkah penyelesaian dan menghafal langkah tidak bermanfaat dalam belajar pemecahan masalah (Muhtarom, Juniati, Siswono, 2017). Mahasiswa dengan kemamampuan matematika tinggi yakin akan pentingnya pemecahan masalah dalam belajar matematika, terutama dalam menyelesaikan soalsoal dalam matematika. Mahasiswa dengan kemampuan matematika tinggi membutuhkan pemahaman konsep dalam menyelesaikan soal pemecahan masalah, tanpa pemahaman konsep, soal tidak bisa dikerjakan dengan benar. Muhtarom juga menjelaskan bahwa subjek dengan keyakinan ke-1 meyakini bahwa dapat memecahkan masalah jika memiliki pemahaman yang baik tentang solusi diperoleh dan meyakini bahwa solusi dari masalah lebih baik daripada berfokus pada jawaban benar. Mahasiswa dengan kemampuan matematika tinggi yakin dengan sering menyelesaikan soal pemecahan masalah, maka akan mengasah kemampuan pemecahan masalah. Mahasiswa dengan kemampuan matematika tinggi juga yakin tentang kegunaan pemecahan masalah dalam kehidupan sehari-hari.

Berdasarkan pemaparan hasil di atas juga diketahui bahwa keyakinan mahasiswa dengan kemampuan matematika sedang membutuhkan waktu untuk menyelesaikan soal-soal pemecaham masalah, memahami dan menentukan konsep dan langkah dengan mencoba beberapa kali. Mahasiswa dengan kemampuan matematika sedang menyelesaikan soal pemecahan masalah tahap demi tahap, mulai dari membuat diketahui, gambar, dan langkah yang dilakukan dengan meghitung tahapantahapanya. Hal ini juga diungkap oleh Muhtarom pada keyakinan jenis ke-1 bahwa subjek meyakini bahwa masalah harus diselesaikan dengan mengikuti langkah penyelesaian dan menghafal langkah tidak bermanfaat dalam belajar pemecahan masalah. Mahasiswa dengan kemamampuan matematika sedang yakin akan pentingnya pemecahan masalah dalam belajar matematika, terutama dalam menyelesaikan soal-soal dalam matematika. Mahasiswa dengan kemampuan sedang membutuhkan pemahaman konsep dalam menyelesaikan soal pemecahan masalah, tanpa pemahaman konsep, soal tidak bisa dikerjakan dengan benar. Muhtarom juga menjelaskan bahwa subjek dengan keyakinan ke-1 meyakini bahwa dapat memecahkan masalah jika memiliki pemahaman yang baik tentang solusi diperoleh dan meyakini bahwa solusi dari masalah lebih baik daripada berfokus pada jawaban benar. Mahasiswa dengan kemampuan matematika sedang yakin dengan sering menyelesaikan soal pemecahan masalah, maka akan mengasah kemampuan pemecahan masalah. Mahasiswa dengan kemampuan matematika sedang juga yakin tentang kegunaan pemecahan masalah dalam kehidupan sehari-hari.

Adapun mahasiswa dengan kemampuan rendah meyakini membutuhkan waktu yang lama (hampir satu jam) dalam menyelesaikan soal pemecahan masalah, serta subjek meyakini adanya solusi dan subjek tidak mendapatkan solusinya. Muhtarom menyatakan bahwa mahasiswa ini berada pada kategori keyakinan jenis ke-1 dimana subjek meyakini dapat menyelesaikan masalah matematika dengan waktu yang lama dan subjek meyakini bahwa setiap masalah memiliki solusi, tetapi ketika menyelesaikan masalah dalam waktu tertentu dan belum didapatkan solusinya, maka subjek akan berhenti menyelesaikannya. Mahasiswa kemampuan rendah merencanakan menyelesaikan soal dengan beberapa langkah, mulai dari menggambar bahkan ada beberapa gambar yang dibuat, dan menentukan konsep beberapa kali. Mahasiswa kemampuan rendah juga meyatakan memerlukan pemahaman konsep dalam pemecahan masalah, apabila konsep tidak diketahui, maka langkah atau hasil akhir akan salah dan harus diulang. Mahasiswa dengan kemampuan matematika rendah yakin tentang pentingnya kemampuan pemecahan masalah dalam matematika sehingga memudahkan dalam penyelesaian soal-soal dalam matematika. Muhtarom menyatakan bahwa mahasiswa dengan keyakinan jenis ke-2 meyakini dapat memecahkan masalah jika memiliki pemahaman yang baik tentang solusi diperoleh dan meyakini bahwa solusi dari masalah lebih baik daripada berfokus pada jawaban yang benar. Mahasiswa dengan kemampuan matematika rendah menyatakan kemampuan pemecahan masalah dapat 
ditingkatkan dengan belajar dan mengerjakan latihan. Hal ini juga diungkap oleh Muhtarom dalam keyakinan jenis ke-2 bahwa subjek meyakini bahwa motivasi, belajar dan latihan dapat meningkatkan kemampuan matematika untuk dapat memecahkan masalah. Mahasiswa dengan kemampuan matematika rendah meyakini tentang pentingnya kemampuan pemecahan masalah dalam kehidupan sehari-hari.

\section{SIMPULAN}

Berdasarkan hasil penelitian diketahui mahasiswa dengan kemampuan berbeda dapat menuliskan prosedur pemecahan masalah, mulai dari memahami masalah, merencanakan, melaksanakan pemecahan masalah dan memeriksa kembali, tetapi hasilnya berbeda pada setiap kemampuan. Keyakinan mahasiswa dalam menyelesaikan soal pemecahan masalah relatif sama untuk semua tingkat kemampuan, yaitu mereka yakin menyelesaikan soal pemecahan masalah membutuhkan waktu yang lama, hanya saja lama waktu yang dibutuhkan untuk masing-masing tingkatan berbeda. Mereka juga yakin bahwa pemecahan masalah berguna dalam matematika dan kehidupan sehari-hari. Mereka juga yakin bahwa kemampuan pemecahan masalah dapat ditingkatkan dengan proses belajar dan pemahaman konsep.

Secara umum, ada perbedaan kemampuan pemecahan masalah antara subjek dengan kemampuan tinggi, sedang, dan rendah. Oleh karena itu, peneliti menyarankan agar para pendidik dan mahasiswa hendaknya menyadari bahwa setiap orang mempunyai potensi yang berbeda dalam pemecahan masalah dan harus ditingkatkan dan jika memungkinkan seorang pendidik lebih memberikan perhatian pada mahasiswa dengan kemampuan rendah. Berdasarkan temuan penelitian ini, diharapkan ada kajian mendalam tentang cara mahasiswa dalam memeriksa kembali penyelesaian masalah pecahan secara lengkap dan mendalam serta ada peneliti lanjutan yang mengkaji juga tentang pemecahan masalah pecahan dengan tinjauan perbedaan jenis kelamin. Sehingga dapat memperkaya teori tentang pemecahan masalah mahasiswa. Diharapkan pada penelitian selanjutnya dapat mengeksplorasi keyakinan subjek dalam menyelesaikan soal berdasarkan tahapan tingkat keyakinan subjek, serta kemampuan subjek dalam membangun keyakinan dalam menyelesaikan soal pemecahan masalah.

\section{UCAPAN TERIMA KASIH}

Kepada pihak kampus dan civitas akademik UIN Ar-Raniry Banda Aceh, khususnya ketua prodi, sekretaris prodi, dosen dan staf prodi Pendidikan Matematika Fakultas Tarbiyah dan Keguruan yang telah memberikan kesempatan kepada peneliti untuk mengembangkan artikel ini.

\section{DAFTAR RUJUKAN}

Ball, D. L. (1990). The Mathematical Understandings That Prospective Teachers Bring to Teacher Education. The Elementary School Journal, 90(4), 449-466.

Haser, C., \& Star, J. R. (2002). Preservice Teacher' Beliefs About Mathematical Understanding. Academic Exchange Quarterly, $147-151$.

Jonassen, D. H. (2000). Toward a Design Theory of Problem Solving. ETR\&D, 48(4), 63-85.

Klossterman, P., Stage, F. K. (1992). Measuring Beliefs About Mathematical Problem Solving. Academic Research Library, 92(3), 109-115.

Llinares, S. (2002). Participation and reification in learning to teach: The role of knowledge and beliefs. In Leder, G.C., Pehkonen, E. \& Törner, G. (Eds.), Beliefs: A Hidden. Netherland: Kluwer Academic Publishers.

Muhtarom, Juniati, D. Siswono, T. Y. E. (2017). Pengembangan terhadap Angket Keyakinan terhadap Pemecahan Masalah dan Pembelajaran Matematika. Jurnal Ilmiah Pendidikan Matematika, 2(1), 55-64.

Nahdataeni. S. (2013). Proses Berpikir Siswa dalam Memecahkan Masalah Sistem Persamaan Linear Dua Variabel Ditinjau dari Gaya Belajar di Kelas X SMA Negeri 2 Palu. Jurnal Elektronik Pendidikan Matematika Tadulako, 2(4), $203-215$.

Nirmalitasari, O. S. (2009). Profil Kemampuan Siswa dalam Memecahkan Masalah Matematika Berbentuk Open-Start Pada Materi Bangun. Jurnal MathEdunesa, 1(1), 1-8.

Nissa, I. C. \& Lestari, P. (2015). Analisis Kemampuan Problem Solving Mahasiswa Calon Guru Matematika Berdasarkan Standar PISA. Jurnal Kependidikan, 14(1), 45-56.

Olving, P. R. S., Etacognition, M., \& Schoenfeld, A. H. (1992). Learning to Think Matematically: Problem solving, Metacogniting, and sense making in mathematics. Internasional Journal for Mathematics Teacher and Learning, 334370.

Pajares, M. F. (2007). Teachers' Beliefs and Educational Research : Cleaning Up a Messy Construct. Review of Educational Research, 62(3), 307-332.

Polya, G. (1957). How to Solve It: A New Aspect of Mathematical Method (Second). New York: Doubleday \& Company.

Raymond, A. M., \& College, K. S. (1997). Inconsistency Between a Beginning Elementary School Teacher's Mathematics Beliefs and Teaching Practice. Journal for Research in Mathematics Education, 28(5), 550-576.

Rosanti, A. S. (2014). Pengetahuan Siswa SMP Kelas VIII dalam Memecahkan Masalah Matematika Non Geometri Berdasarkan Level 2 Perkembangan Berpikir Van Hiele. Jurnal Elektronik Pendidikan Matematika, 1(2), 19-31. 
Uçar, Z. T. (2010). İlköğretim Öğrencilerinin Matematik, Matematik Öğretmenleri ve Matematikçiler Hakkındaki İnançları Elementary Students' Beliefs about Mathematics, Mathematics' Teachers and Mathematicians. Education and Science, $35(155), 131-144$.

Yavuz, G., \& Erbay, H. N. (2015). The analysis of pre- service teachers' beliefs about mathematical problem solving. Procedia - Social and Behavioral Sciences, 174, 2687-2692. https://doi.org/10.1016/j.sbspro.2015.01.953

Yurizka. M. S. (2012). Profil Kemampuan Siswa SMP dalam Memecahkan Masalah Matematika Open-Ended Materi Pecahan Berdasarkan Tingkat Kemampuan Matematika. Jurnal MathEdunesa, 1(1), 26-34. 